\title{
PENGARUH KOMUNIKASI PEMASARAN TERPADU TERHADAP PENERIMAAN BRAND CHOCOLICIOUS
}

\author{
Fitriyana Abdullah' ${ }^{1}$, Raidah Intizar ${ }^{2}$ \\ Program Studi Ilmu Komunikasi, FISIP, Universitas Islam Makassar \\ email: 1fitriyanaabdullahh@gmail.com,2raidahintizar.dty@uim-makassar.ac.id
}

\begin{abstract}
This study aims to examine the effect of Integrated Marketing Communication on the acceptance of the Chocolicious brand as a booming cake shop in Makassar. This research was conducted by using quantitative methods, purposive sampling, which includes standard criteria with the Chocolicious brand and captured 160 respondents in this study. The results of the research through multiple regression test show that the IMC, which includes direct marketing, sales promotion, public relations, personal selling, and advertising simultaneously affects 68.7 per cent of Chocolicious brand acceptance. In contrast, in the coefficient analysis, it shows that only advertising and public relations significantly influence the acceptance of the Chocolicious brand so these two things should be maintained, and evaluating other IMC strategies.
\end{abstract}

Keyword: integrated marketing communication; social media ads; UMKM

\begin{abstract}
ABSTRAK
Penelitian ini bertujuan untuk menguji pengaruh Komunikasi Pemasaran Terpadu terhadap penerimaan brand Chocolicious sebagai toko kue yang sedang melejit di Makassar. Penelitian ini dilakukan dengan metode kuantitatif, purposive sampling yang mencakup kriteria familiar dengan brand Chocolicious menjaring 160 responden dalam penelitian ini. Hasil penelitian melalui uji regresi berganda menunjukkan bahwa KPT yang meliputi pemasaran langsung, promosi penjualan, hubungan masyarakat, penjualan personal, dan iklan secara bersama-sama mempengaruhi 68,7 persen penerimaan brand Chocolicious, sementara dalam analisis koefisien menunjukkan bahwa hanya periklanan dan hubungan masyarakat yang berpengaruh secara signifikan pada penerimaan brand Chocolicious sehingga kedua hal ini patut dipertahankan dan mengevaluasi strategi KPT lainnya.
\end{abstract}

Kata kunci: komunikasi pemasaran terpadu, iklan sosial media, UMKM

\section{PENDAHULUAN}

Data dari Kementerian Koperasi dan Usaha Kecil Menengah (Kemenkop UKM) menunjukkan bahwa sebesar 3,79 juta usaha mikro, kecil, dan menengah (UMKM) sudah memanfaatkan platform daring untuk memasarkan produknya (Ayu Yuliani, 2019). Hal ini menjadi lazim mengingat bahwa pedagang akan memasarkan produknya pada tempat di mana terdapat banyak calon pembeli, meninjau data bahwa sebagian besar masyarakat telah terkoneksi dengan dunia maya, yakni 64 persen atau sekitar
272,1 juta populasi di Indonesia (Pertiwi, 2020).

Riuhnya internet mengundang para pelaku UMKM untuk memasarkan produknya pada platform daring, sehingga persaingan menjadi lebih ketat. Kreatifitas di dalam perpaduan dari berbagai bentuk komunikasi pemasaran menjadi sebuah tren yang terus menanjak, tidak terkecuali bagi toko kue Chocolicious.

Chocolicous merupakan brand yang pernah viral secara nasional, disebabkan peristiwa penolakan pihak toko tersebut untuk menuliskan kalimat religius pada kue, hal ini sempat mengundang salah satu koki 
kenamaan, yakni Junior Rorimpandey (Chef Juna) untuk ikut mengkritik sebelum akhirnya meminta maaf pada manajemen toko (Anar, 2018).

Namun Toko Kue ini sudah terkenal di kalangan penikmat bakery dan pastry sebelum viral karena kontroversi tersebut. Toko kue Chocolicious merupakan brand yang berdiri sejak 2013 di kota Makassar. Sebagai UMKM, Chocolicious berkembang cukup pesat dan berhasil menantang brand besar yang sudah lama bergelut di bidang bakery dan pastry.

Hal ini terjadi karena gesitnya Chocolicious menjawab tantangan zaman dengan adopsi komunikasi pemasaran terpadu di media baru. Alhasil, toko kue ini menjadi cukup populer dan menjadi UMKM yang patut diteladani bagi UMKM pemula yang memiliki visi untuk menjadi UMKM taraf nasional.

Pemilik sekaligus pendiri Chocolicious adalah seorang dokter gigi bernama Fika Kurniawati, Fika mengaku tertarik pada dunia bakery \& pastry setelah menghadiri acara demo masak di Makassar Golden Hotel lalu membuat brownies Amerika pertamanya. Sejak 2013 ia mulai mengembangkan bisnisnya di skala insutri rumahan dengan berjualan online selama tujuh bulan. Namun meski kurang berhasil, ini tidak menyurutkan keinginannya untuk mengembangkan usaha. Keluarganya pun mendukung secara penuh, dan Fika memutuskan berhenti praktik dokter gigi dan fokus menekuni bisnis dengan brand Chocolicious miliknya.

Fika sukses membawa brand Chocolicious hingga memiliki sejumlah gerai di kota Makassar, dengan mengusung tagline "Premium Cookies \& Cake" dan menarget pasar menengah atas. Chocolicious berkomitmen menghadirkan produk dengan kualitas terbaik dan nomor satu di Makassar. Hal ini membawa brand tersebut menerima banyak penghargaan seperti Produk Halal Pendatang Baru Terbaik dari LPPOM Majelis Ulama Indonesia, Most Favorite Culinary Instagram 2018, dan masih banyak lagi.
Penelitian ini tertarik untuk menguji apakah komunikasi pemasaran terpadu yang diterapkan toko kue Chocolicious memiliki dampak terhadap penerimaan brand toko kue tersebut. Penelitian ini juga tertarik mengeksplorasi indikator komunikasi pemasaran apa yang diterapkan oleh Chocolicious yang memiliki pengaruh seignifikan pada penerimaan brand. Tujuan penelitian ini adalah memberikan saran berarti kepada pelaku-pelaku UMKM sejenis Chocolicious agar dapat mempelajari langkah-langkah efektif toko tersebut dalam hal komunikasi pemasaran. Penelitian ini juga ingin memberikan masukan kepada pihak Chocolicious mengenai strategi komunikasi pemasaran yang dilakukannya dan terbukti memberikan dampak atas penerimaan brandnya.

Penelitian ini merupakan penelitian pertama yang menganalisis dan membandingkan efektifitas integrated marketing communication yang dilakukan oleh brand Chocolicious, sebagai sebuah perusahaan yang benar-benar menjalankan perpaduan dari beberapa strategi marketing komunikasi. Peneliti berharap hasil dari penelitian ini juga dapat bermanfaat bagi perusahaan lain yang ingin memadukan berbagai elemen komunikasi pemasaran sehingga tercapai hasil maksimal dalam investasi di bidang komunikasi pemasaran.

Komunikasi pemasaran terpadu adalah sebuah konsep sederhana di mana alat untuk pemasaran dipadukan sedimikian rupa sehingga bekerja dalam harmoni untuk menghasilkan laba bagi perusahaan. Secara umum, terdapat lima strategi komunikasi pemasaran terpadu, yakni.

Pemasaran langsung (Direct Marketing) adalah kegiatan perusahaan melakukan pemasaran secara langsung kepada konsumen.

Promosi penjualan (Sales Promotion) adalah insentif jangka pendek yang diberikan pada konsumen agar konsumen mau membeli barang atau menggunakan jasa. Kegiatan seperti launching atau kegiatan lainnya di luar kegiatan jual beli 
biasa juga dapat menjadi agenda promosi penjualan.

Hubungan Masyarakat (Public Relation) adalah bagaimana perusahaan memberikan layanan, seperti kejelasan produk, bantuan, dan maintenance.

Penjualan Personal (Personal Selling) adalah penjualan yang bersifat pribadipribadi, seperti reward khusus karena telah berlangganan, atau potongan harga khusus karena beberapa syarat yang dipenuhi oleh konsumen.

Periklanan (Adversting) adalah kegiatan perusahaan memperkenalkan produk melalui media cetak, media elektronik, dan media baru.

Komunikasi Pemasaran Terpadu atau Integrated Marketing Communication menggabungkan kelima strategi di atas secara terpadu untuk menguatkan pemasarannya. Hal inilah yang menyebabkan strategi ini disebut sebagai Komunikasi Pemasaran Terpadu atau Integrated Marketing Comunication (IMC).

Beberapa penelitian pernah membahas bagaimana pengaruh komunikasi pemasaran terpadu terhadap penerimaan brand, sebagaimana dalam penelitian berjudul "Pengaruh Komunikasi Pemasaran Terpadu terhadap Ekuitas Merek" (Kartikasari, 2014) yang bertujuan untuk mengetahui efek KPT terhadap ekuitas merek khsusunya dalam bisnis perhotelan di Semarang. Peneliti membagikan kuisioner kepada 100 responden yang merupakan pelanggan dan menginap di hotel di Semarang. Hasil penelitian menunjukkan bahwa variabel Komunikasi Pemasaran Terpadu seperti Promosi Penjualan, Penjualan Pribadi, dan Hubungan Masyarakat secara bersama-sama berpengaruh terhadap ekuitas merek. Namun saat ditelaah lebih lanjut, hanya variable Promosi Penjualan, yakni insentif jangka pendek yang diberikan pada konsumen yang berpengaruh signifikan terhadap Ekuitas Merek hotel di Semarang.

Yulianti Keke (2015), juga melakukan penelitian dengan topik KPT, penelitian yang dilakukan di STMT Trisakti ini bertujuan untuk mencari tahu apa efek KPT terhadap pemilihan universitas siswa, dan hasil dari penelitian menemukan bahwa Komunikasi Pemasaran Terpadu yang meliputi Periklanan, Promosi Penjualan, Penjualan Pribadi, Hubungan Masyarakat, dan Pemasaran Langsung, bersama-sama dan sebagian melalui Kesadaran Merek dapat memengaruhi kesadaran merek sehingga berdampak pada keputusan siswa pada universitas mana yang mereka pilih. Namun, hanya Hubungan Masyarakat yang memiliki pengaruh signifikan terhadap Kesadaran Merek.

Selanjutnya adalah penelitian Jehuda Ghrahito Hutomo Krussell, Eristia Lidia Paramita (2016) yang berjudul Komunikasi Pemasaran Terpadu Dan Ekuitas Merek Alfamart. Penelitian ini berangkat dari semakin menjamurnya bisnis ritel di Indonesia yang menjadikan kompetisi merek menjadi sangat ketat. Hal ini menjadikan strategi Komunikasi Pemasaran Terpadu perlu dimiliki oleh perusahaan ritel. Penelitian ini khususnya ingin mengetahui apakah strategi KPT yang diterapkan oleh Alfamart sukses untuk meningkatkan ekuitas merek. Sebanyak 150 responden dipilih melalui metode purposive sampling. Analisis data menggunakan regresi linier berganda. Temuan penelitian menunjukkan bahwa dimensi komunikasi pemasaran terintegrasi terdiri dari Periklanan, Promosi Penjualan, Penjualan Pribadi, Hubungan Masyarakat, Pemasaran Langsung, Pemasaran Interaktif, dan Desain Perusahaan secara bersama-sama memengaruhi Ekuitas Merek Alfamart. Namun melalui penelusuran lebih lanjut didapati bahwa hanya Promosi Penjualan, Penjualan Pribadi, dan Desain Perusahaan yang secara signifikan memengaruhi ekuitas merek Alfamart.

Dari beberapa penelitian di atas dapat diamati bahwa perpaduan berbagai strategi dapat berpengaruh pada baik ekuitas merek maupun kesadaran merek, namun jika didalami lebih lanjut perusahaan perhotelan yang menawarkan insentif jangka pendek kepada konsumen cenderung meningkatkan ekuitas merek, dan pada institusi pendidikan 
seperti universitas, hubungan masyarakat menjadi aspek yang penting untuk meningkatkan brand awareness. Lebih lanjut pada perusahaan ritel, perpaduan komponen dapat berdampak pada ekuitas merek.

Penelitian ini bertujuan meneliti dari Komunikasi Pemasaran Terpadu yang telah dijalankan oleh salah satu UMKM bidang kuliner yang tergolong sukses di Makassar, sehingga dapat menjadi masukan bagi UMKM di Makassar, dan secara umum di Indonesia.

\section{METODE}

Penelitian ini merupakan penelitian kuantitatif yang dilakukan dengan cara membagikan kuesioner kepada konsumen Chocolicious di Makassar untuk mengetahui penerimaan masyarakat terhadap Brand Chocolicious serta bagaimana komunikasi pemasaran terpadu yang diterapkan di Chocolicious.

Teknik pengambilan sampel yang digunakan adalah purposive sampling adalah teknik untuk menentukan sampel dari populasi dengan kriteria tertentu. (Sugiyono, 2012, p.85). Teknik sampling ini digunakan karena tidak ada data definitif mengenai pembeli atau pelanggan tetap toko kue Chocolicious sehingga peneliti menerapkan kuota sebanyak 100 orang sebagai sampel penelitian dengan memiliki ciri-ciri atau kriteria sebagaimana yang ditetapkan oleh peneliti.

Data lalu dianalisis dengan analisis regresi.

\section{HASIL DAN PEMBAHASAN}

Pengumpulan data kuantitatif pada penelitian ini dilakukan dengan cara penyebaran kuesioner kepada konsumen Chocolicious di Makassar, Adapun deskripsi karakteristik responden dari penelitian ini meliputi:

Tabel 1

Jenis Kelamin

\begin{tabular}{lll}
\hline \multirow{2}{*}{ Keterangan } & \multirow{2}{*}{ Frekuensi } & Persentas \\
\hline
\end{tabular}

\begin{tabular}{|c|c|c|}
\hline Laki-laki & 33 & $25,4 \%$ \\
\hline Perempuan & 97 & $74,6 \%$ \\
\hline \multicolumn{3}{|c|}{ Sumber: Peneliti, 2019} \\
\hline Keterangan & Frekuensi & $\begin{array}{l}\begin{array}{l}\text { Persent } \\
\text { ase }\end{array} \\
\end{array}$ \\
\hline$<20$ tahun & 30 & $23,1 \%$ \\
\hline 20-30 tahun & 87 & $66,9 \%$ \\
\hline 31-40 tahun & 6 & $4,6 \%$ \\
\hline$>40$ tahun & 7 & $5,4 \%$ \\
\hline $\begin{array}{l}\text { Sumber: Pene } \\
\text { Tabel } 3 \\
\text { Pendidikan T }\end{array}$ & $\begin{array}{l}2019 \\
\text { khir } \\
\end{array}$ & \\
\hline
\end{tabular}

\begin{tabular}{lll}
\hline Keterangan & Frekuensi & $\begin{array}{c}\text { Persent } \\
\text { ase }\end{array}$ \\
\hline Sd & 0 & $0 \%$ \\
\hline SMP & 2 & $1,5 \%$ \\
\hline SMA/SMK & 93 & $71,5 \%$ \\
\hline Sarjana & 30 & $23,1 \%$ \\
\hline Magister & 4 & $3,1 \%$ \\
\hline Doktor & 1 & $0,8 \%$ \\
\hline $\begin{array}{l}\text { Tabel 4 } \\
\text { Pekerjaan }\end{array}$ & Sumber : Peneliti, 2019 \\
\hline Keterangan & Frekuensi & $\begin{array}{c}\text { Persent } \\
\text { ase }\end{array}$ \\
\hline
\end{tabular}

\begin{tabular}{lll}
\hline $\begin{array}{c}\text { Karyawan } \\
\text { Swasta }\end{array}$ & 30 & $23,1 \%$ \\
\hline $\begin{array}{c}\text { Guru } \\
\text { Pegawai } \\
\text { Negeri }\end{array}$ & 3 & $2,3 \%$ \\
\hline $\begin{array}{c}\text { Mahasiswa } \\
\text { atau Siswa }\end{array}$ & 64 & $5,4 \%$ \\
\hline Wiraswasta & 11 & $49,2 \%$ \\
\hline $\begin{array}{c}\text { Ibu Rumah } \\
\text { Tangga }\end{array}$ & 6 & $8,5 \%$ \\
\hline $\begin{array}{c}\text { Pengusaha } \\
\text { Belum ada }\end{array}$ & 4 & $4,6 \%$ \\
\hline
\end{tabular}

Sumber : Peneliti, 2019

Sampel yang digunakan dalam penelitian ini sebanyak 130 orang yang berdomisili di Makassar yang sudah pernah membeli Chocolicious di Makassar. 
Penelitian dimulai pada pekan terakhir bulan April. Penelitian ini dilaksanakan selama dua bulan, hal ini sesuai dengan kebutuhan peneliti, untuk pengambilan data lain sesuai kebutuhan penelitian dilaksanakan diluar jadwal penelitian yang ditentukan. Pada penelitian ini, peneliti membagikan kusioner kepada konsumen Chocolicious di Makassar.

Pada penelitian ini, peneliti melakukan uji analisis data menggunakan teknik Uji Analisis Regresi Linier dengan bantuan program SPSS statistics 25. Sebelum menganalisis dengan Analisis Regresi Linier tersebut, peneliti memenuhi uji prasyarat yang harus dipenuhi yaitu uji validitas dan uji reliabilitas pada tes soal.

Data dalam penelitiaan ini, peneliti peroleh dari angket atau kuesioner yang peneliti bagikan kepada konsumen Chocolicious di Makassar. Terkait kusioner yang dibagikan tersebut, peneliti membuat pedoman kusioner. Penelitian ini mengembangkan dua variabel dengan menggunakan skala likert 1 (sangat tidak setuju) sampai 5 (sangat setuju). Dua variabel tersebut adalah Komunikasi pemasaran terpadu dan penerimaan brand Chocolicious. Berikut ini peneliti uraikan masing-masing variabel dalam penelitian ini.

Deskripsi Data Variabel X (Komunikasi pemasaran terpadu)

Data variabel komunikasi pemasaran terpadu diperoleh dari angket dengan 5 indikator yang menjadi tolak ukur dalam penelitian ini yaitu pemasaran langsung, promosi penjualan, hubungan masyarakat, penjualan personal,dan periklanan Total item pernyataan dari 5 indikator tersebut ialah 15 pernyataan.

Deskripsi Data Variabel Y (Penerimaan brand Chocolicious)

Variabel penerimaan brand Chocolicous terdapat 4 indikator yaitu kesadaran merek, asosiasi merek, persepsi kualitas, dan loyalitas merek.Total item pernyataan dari 4 indikator penerimaan brand Chocolicous tersebut ialah 14 pernyataan.

Analisis Data
Selain dua variabel skala yang ditetapkan yakni Komunikasi pemasaran terpadu (X) dan Penerimaan brand Chocolicious (Y) penulis juga menetapkan 4 variabel kategori sebagai variabel kontrol yakni jenis kelamin, usia, pendidikan, dan pekerjaan. penulis melakukan uji $\mathrm{T}$ test pada satu variabel nominal yakni jenis kelamin, dan ANOVA pada tiga variabel nominal yakni usia, pendidikan, dan pekerjaan untuk memastikan bahwa tidak ada bias dari hasil penelitian.

Berdasarkan hasil output software SPSS 25, didapatkan hasil uji T bahwa pada jenis kelamin laki-laki $(\mathrm{M}=3.95, \mathrm{SD}=.69)$ lebih tinggi dari nilai jenis kelamin perempuan $(\mathrm{M}=3.94 \mathrm{SD}=.67)$ namun perbedaan ini tidak signifikan $\mathrm{t}(53.4)=.50, p=.782$.

Pada kategori jenis kelamin dapat disimpulkan bahwa tidak ada bias. Artinya konsumen Chocolicious berdasarkan jenis kelamin, tidak sebanding tapi tetap hasilnya tidak signifikan, dan tidak ada perbedaan antara laki-laki maupun perempuan.

ANOVA dilakukan untuk pilihan jawaban yang lebih dari dua yaitu kategori usia, pendidikan, dan pekerjaan. Pada usia $(p=.248)$, pendidikan $(p=.757), \quad$ dan pekerjaan $(p=.175)$.

Hasil uji SPSS menunjukkan bahwa tidak ada perbedaan yang signifikan dalam penerimaan brand Chocolicious berdasarkan jenis kelamin, usia, pendidikan, dan pekerjaan, karena nilai probabilitasnya lebih besar dari nilai 0.05 .

Tabel 5

Perbedaan Variabel Kategori

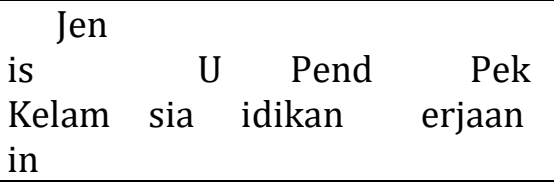

\section{Peneri}

maan

brand

.78

Chocolici

ous

\section{Sumber: Peneliti, 2019}

Selanjutnya penulis melakukan uji relibilitas, dan uji hipotesis yaitu sebagai berikut: 
Uji Reliabilitas

Tabel 6

Uji Realibitas

\begin{tabular}{|c|c|c|c|}
\hline \multirow[b]{2}{*}{ Variab } & \multicolumn{3}{|c|}{ Alph } \\
\hline & $\begin{array}{l}\text { Indika } \\
\text { tor }\end{array}$ & $\begin{array}{l}\text { a } \\
\text { Cronba } \\
\text { ch }\end{array}$ & $\begin{array}{l}\text { Ketera } \\
\text { ngan }\end{array}$ \\
\hline \multirow{5}{*}{$\begin{array}{l}\quad \text { Komun } \\
\text { ikasi } \\
\text { Pemasara } \\
\text { n Terpadu }\end{array}$} & \begin{tabular}{l}
\multicolumn{1}{c}{ Pemas } \\
aran \\
Langsung
\end{tabular} & .802 & el Reliab \\
\hline & $\begin{array}{l}\text { Promo } \\
\text { si } \\
\text { Penjuala } \\
n\end{array}$ & .820 & el $\begin{aligned} & \text { Reliab }\end{aligned}$ \\
\hline & $\begin{array}{l}\text { Hubun } \\
\text { gan } \\
\text { Masyarak } \\
\text { at }\end{array}$ & .911 & $\begin{array}{l}\text { Sangat } \\
\text { Reliabel }\end{array}$ \\
\hline & $\begin{array}{l}\quad \text { Penju } \\
\text { alan } \\
\text { Personal } \\
\end{array}$ & .839 & el $\begin{aligned} \text { Reliab } \\
\end{aligned}$ \\
\hline & Iklan & .865 & $\begin{array}{l}\text { Reliab } \\
\text { el }\end{array}$ \\
\hline \multirow{5}{*}{$\begin{array}{l}\quad \text { Peneri } \\
\text { maan } \\
\text { Brand } \\
\text { Chocolicio } \\
\text { us }\end{array}$} & \begin{tabular}{l}
\multicolumn{1}{c}{ Kesad } \\
aran \\
merk
\end{tabular} & \multirow{5}{*}{.945} & \multirow{5}{*}{$\begin{array}{l}\text { Sangat } \\
\text { Reliabel }\end{array}$} \\
\hline & $\begin{array}{l}\text { Asosia } \\
\text { si Merk }\end{array}$ & & \\
\hline & $\begin{array}{l}\text { Perse } \\
\text { psi }\end{array}$ & & \\
\hline & Kualitas & & \\
\hline & $\begin{array}{r}\text { Loyali } \\
\text { tas Merk }\end{array}$ & & \\
\hline
\end{tabular}

\section{Sumber : Peneliti, 2019}

Berdasarkan perhitungan SPSS 25 pada tabel Reliability Statistics, nilai Cronbach's Alpha setiap item pada instrument tersebut adalah reliable. Jadi responden menunjukkan bahwa responden memiliki konsistensi.

3) Uji Regresi Linier Berganda

Tabel 7

Model Summary

Std

Adjus Error of

\begin{tabular}{crrrrr}
$\begin{array}{c}\text { Mo } \\
\text { del }\end{array}$ & \multicolumn{2}{c}{$\begin{array}{l}\text { Squar } \\
\text { e }\end{array}$} & Square & \multicolumn{2}{l}{$\begin{array}{l}\text { Estimat } \\
\mathrm{e}\end{array}$} \\
\hline 1 & ${ }^{.8}$ & $9^{\mathrm{a}}$ & .69 & .687 & $7^{.3782}$ \\
\hline
\end{tabular}

a. predictors (Constant)

Tabel 8

ANOVAa

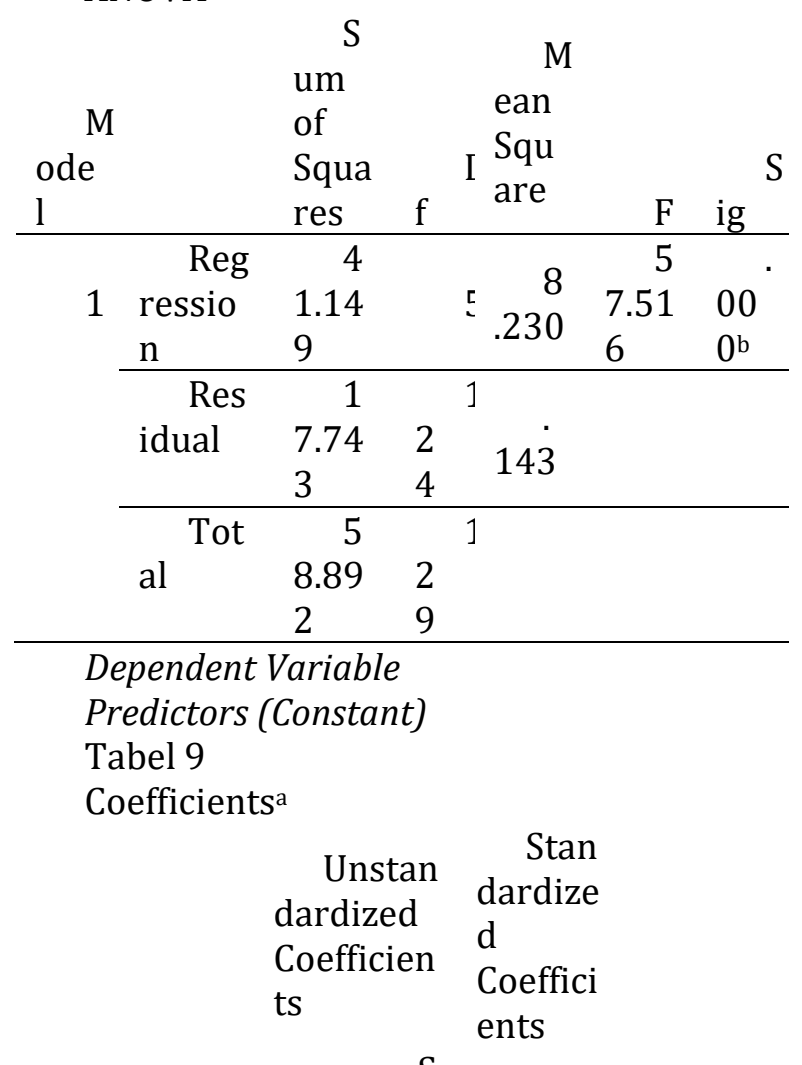

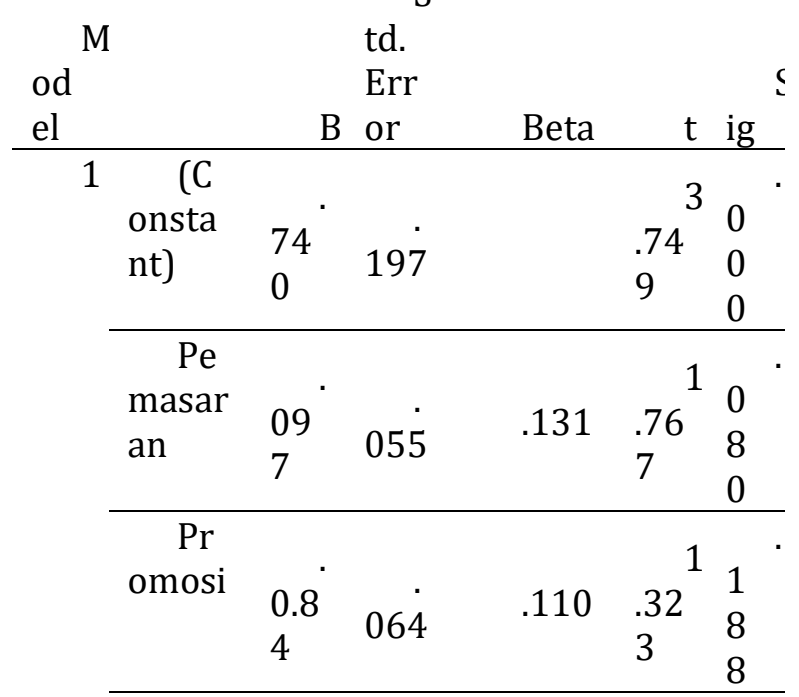

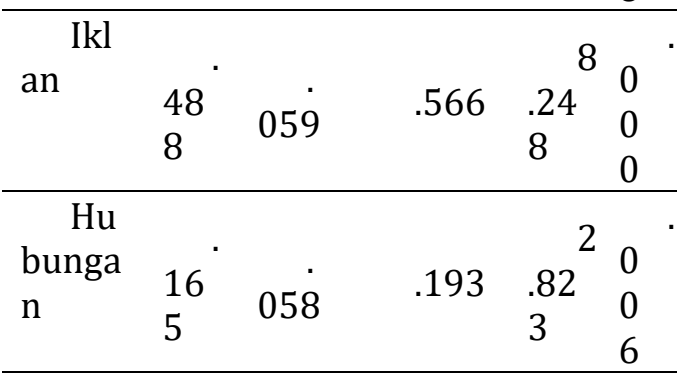

Fakultas Ilmu Sosial Dan Ilmu Politik

Universitas Indonesia Timur 


\begin{tabular}{|c|c|c|c|c|}
\hline $\mathrm{Pe}$ & & & & \\
\hline njuala & 03 & & - & 68 \\
\hline$n$ & 0 & 044 & .042 & 2 \\
\hline
\end{tabular}

Dependent Variable

Sumber : Peneliti, 2019

Penjelasan dari tabel di atas adalah sebagai berikut:

Pada output Model Summary tertulis Adjusted $R$ Square mempunyai nilai 0,687 yang artinya persentase sumbangan variabel komunikasi pemasaran terpadu sebesar $68,7 \%$. Komunikasi pemasaran terpadu mempunyai peran yang sangat besar dalam penerimaan brand. Sedangkan sisanya sebesar 31,3\% dipengaruhi oleh variabel eksternal.

Pada output Model Summary tertulis Standard Error of the Estimate mempunyai nilai .378. Standard Error of the Estimate adalah ukuran kesalahan prediksi. Dalam kasus ini, kesalahan dapat terjadi dalam memprediksi nilai penerimaan brand Chocolicious sebesar .378.

Berdasarkan output Coefficients ${ }^{a}$ diperoleh kesimpulan yang menjelaskan bahwa hubungan antara komunikasi pemasaran terpadu dengan penerimaan brand sangat berhubungan atau sangat signifikan.

Pada tabel 5.33 output ANOVA tertulis bahwa taraf nilai Sig. 0,000 dan taraf 5\%. Dari tabel di atas diketahui bahwa nilai Sig.= $0,000<0,05$. Sehingga dapat ditarik kesimpulan bahwa komunikasi pemasaran terpadu dan penerimaan brand sangat berhubungan atau sangat signifikan. Artinya bahwa komunikasi pemasaran terpadu memberikan pengaruh sebesar 68,7\% terhadap penerimaan brand, sedangkan sisanya 31,3\% dipengaruhi oleh variabel lain di luar komunikasi pemasaran terpadu.

Analisis regresi linear berganda ini digunakan untuk menjawab rumusan masalah yang telah diajukan oleh peneliti.

\section{Pembahasan}

Chocolicious merupakan salah satu perusahaan yang menerapkan komunikasi Pemasaran Terpadu. Hasil analisis penelitian ini menunjukkan bahwa iklan yang terdiri dari pernyataan; 1) Saya sering mendapatkan informasi produk dan promo Chocolicious melalui iklan di media sosial; 2) Iklan yang dilakukan Chocolicious di media sosial itu efektif; 3) Saya tertarik membeli produk Chocolicious karena iklan di media sosial. Iklan media sosial memiliki pengaruh positif dan signifikan terhadap keputusan pembelian Chocolicious. Ini menggambarkan bahwa semakin tinggi iklan yang dikeluarkan perusahaan maka akan semakin tinggi pula keputusan pembelian yang akan dilakukan konsumen pada Chocolicious.

Di samping iklan, hubungan masyarakat yang dilakukan oleh pihak perusahaan Chocolicious juga terbukti memberikan dampak pada kesadaran merek. Item dalam hubungan masyarakat ini antara lain; 1) Menurut saya, Chocolicious melayani setiap keluhan dari pelanggannya; 2) Menurut saya, Chocolicious memperhatikan kebutuhan dari pelanggannya; 3) Menurut saya, saat mendapatkan kritik dan masukan, Chocolicious segera membenahi pelayanan dan kualitas produknya.

Iklan dapat dimanfaatkan secara efektif untuk membangun informasi produk jangka panjang dan dapat memicu pembelian segera. Iklan merupakan semua bentuk terbayar dari presentasi nonpribadi dan promosi ide, barang, atau jasa oleh sponsor tertentu Kotler dan Armstrong (2008). Hal ini sesuai dengan teori yang dikemukakan oleh Tjiptono (2008), "iklan adalah bentuk komunikasi tidak langsung yang didasari pada informasi tentang keunggulan dan keuntungan suatu produk yang disusun sedemikian rupa sehingga menimbulkan rasa yang menyenangkan akan mengubah fikiran seseorang untuk melakukan pembelian". Sehingga semakin tinggi frekuensi iklan yang keluarkan perusahaan maka intensitas pemberian informasi akan semakin sering dilakukan. Informasi yang sering dilakukan akan membuat konsumen semakin cepat mengetahui produk yang ditawarkan yang merangsang konsumen lebih cepat melakukan keputusan pembelian. 
Integrated Marketing Communications merupakan konsep perencanaan komunikasi pemasaran yang mengakui nilai tambah rencana komprehensif yang mengkaji peran strategis masing-masing bentuk komunikasi dan memadukannya untuk meraih kejelasan, konsistensi, dan dampak komunikasi maksimal melalui pengintegrasian pesan. Komunikasi pemasaran terpadu juga merupakan sebuah proses strategi bisnis dalam mengelola hubungan dengan konsumen yang intinya untuk menggerakkan brand value. Kegiatan komunikasi pemasaran memang merupakan salah satu hal yang juga menentukan citra dari produk itu sendiri. Hal tersebut dilakukan berdasarkan bahwa dalam setiap proses komunikasi pemasaran yang dilakukan terdapat informasi tentang karakteristik dari produk itu sendiri. Karena perusahaan yakin bahwa citra merek dibangun oleh beberapa faktor yang salah satunya ialah kegiatan komunikasi pemasaran.

Hasil dari penelitian ini turut mendukung penelitian terdahulu yang membahas bagaimana pengaruh komunikasi pemasaran terpadu terhadap penerimaan brand, sebagaimana dalam Kartikasari (2014) yang menunjukkan bahwa variabel Komunikasi Pemasaran Terpadu seperti Promosi Penjualan, Penjualan Pribadi, dan Hubungan Masyarakat secara bersama-sama berpengaruh terhadap ekuitas merek. Namun saat ditelaah lebih lanjut, hanya variable Promosi Penjualan, yakni insentif jangka pendek yang diberikan pada konsumen yang berpengaruh signifikan terhadap Ekuitas Merek hotel di Semarang.

Dalam penelitian Yulianti Keke (2015), juga ditemukan bahwa Komunikasi Pemasaran Terpadu yang meliputi Periklanan, Promosi Penjualan, Penjualan Pribadi, Hubungan Masyarakat, dan Pemasaran Langsung, bersama-sama dan sebagian melalui Kesadaran Merek dapat memengaruhi kesadaran merek sehingga berdampak pada keputusan siswa pada universitas mana yang mereka pilih. Namun, hanya Hubungan Masyarakat yang memiliki pengaruh signifikan terhadap Kesadaran Merek.

Selanjutnya adalah penelitian Jehuda Ghrahito Hutomo Krussell, Eristia Lidia Paramita (2016) menunjukkan bahwa dimensi komunikasi pemasaran terintegrasi terdiri dari Periklanan, Promosi Penjualan, Penjualan Pribadi, Hubungan Masyarakat, Pemasaran Langsung, Pemasaran Interaktif, dan Desain Perusahaan secara bersamasama memengaruhi Ekuitas Merek Alfamart. Namun melalui penelusuran lebih lanjut didapati bahwa hanya Promosi Penjualan, Penjualan Pribadi, dan Desain Perusahaan yang secara signifikan memengaruhi ekuitas merek Alfamart.

Dari beberapa penelitian di atas dapat diamati bahwa perpaduan berbagai strategi dapat berpengaruh pada baik ekuitas merek maupun kesadaran merek, namun jika didalami lebih lanjut perusahaan perhotelan yang menawarkan insentif jangka pendek kepada konsumen cenderung meningkatkan ekuitas merek, dan pada institusi pendidikan seperti universitas, hubungan masyarakat menjadi aspek yang penting untuk meningkatkan brand awareness. Lebih lanjut pada perusahaan ritel, perpaduan komponen dapat berdampak pada ekuitas merek.

Penelitian ini memberi khazanah tambahan bahwa untuk bisnis kuliner, strategi komunikasi pemasaran yang berdampak pada penerimaan merek adalah iklan media sosial dan hubungan masyarakat.

\section{SIMPULAN DAN SARAN}

\section{Simpulan}

Berdasarkan hasil penelitian dan pembahasan yang telah dilaksanakan, maka kesimpulan pada penelitian ini adalah sebagai berikut:

Komunikasi pemasaran terpadu (integrated marketing communications) telah banyak diterapkan oleh perusahaan yang akan meluncurkan sebuah produk baru. Atau perusahaan yang baru membangun merek perusahaannya. Akan tetapi pada 
realitanya, Integrated Marketing Communications (IMC) sangat jarang digunakan bagi penyelenggara event untuk mendapatkan hati calon pelanggannya. Padahal sangat diperlukan dan penting di terapkan dalam pembuatan sebuah kegiatan sebelum kegiatan tersebut direalisasikan. Sehingga Chocolicious menjadi perusahaan dengan peningkatan yang baik dan disukai banyak masyarakat.

Pengaruh komunikasi pemasaran terpadu terhadap penerimaan brand yaitu sebesar $68.7 \%$ artinya komunikasi pemasaran terpadu mempunyai peran yang sangat besar dalam penerimaan brand. Berdasarkan hasil mengenai komunikasi pemasaran terpadu Chocolicious yang dilakukan di Makassar menempatkan iklan dalam teks memiliki nilai tertinggi, dan urutan kedua yaitu hubungan masyarakat. Komunikasi pemasaran terpadu yang terdiri dari pemasaran langsung, promosi penjualan, hubungan masyarakat, penjualan personal, dan iklan dalam penerimaan brand. Semua komponen diatas signifikan tetapi hanya dua komponen yang paling menentukan penerimaan brand Chocolicious yaitu iklan dan hubungan masyarakat. Promosi yang dilakukan di media sosial ternyata sangat bemanfaat terhadap konsumen Chocolicious. Terbukti dengan banyaknya konsumen yang tertarik dan ingin membeli cake dari toko Chocolicious dengan promosi yang ada di Media sosial, atau dengan promosi yang mereka dapatkan dari media sosial.

\section{Saran}

Berdasarkan hasil penelitian dan pengamatan selama penelitian, peneliti melihat pada beberapa hal yang perlu diperhatikan dan diharapkan dapat menjadi masukan yang positif demi kebaikan bersama. Adapun saran tersebut yaitu :

Perusahaan sebaiknya dapat mempertahankan promosi dengan menggunakan iklan di media sosial, karena hal ini sangat efektif untuk konsumen Chocolicious. Dengan adanya promosi di media sosial konsumen Chocolicious merasa antusias dan tertarik ingin datang membeli cake. Dan perusahaan agar kiranya mempertahankan hubungan masyarakat yang dilakukan Chocolicious karena dengan adanya hubungan masyarakat dalam perusahaan, konsumen merasa senang dengan menerapkan hubungan masyarakat yang bagus.

Terkait dengan komunikasi pemasaran terpadu Chocolicious yang diilakukan pada konsumen Chocolicous di Makassar, komponen penjualan personal, promosi penjualan, dan pemasaran langsung yaitu jika ingin memaksimalkan komunikasi pemasaran terpadu harus ditingkatkan kembali tiga komponen tersebut, karena dari lima komponen komunikasi pemasaran terpadu hanya dua komponen yang signifikan atau bermanfaat untuk konsumen Chocolicious. bukan berarti penjualan personal, pemasaran langsung, dan promosi penjualan tidak bermanfaat tetapi perlu ditingkatkan kembali atau di evaluasi.

\section{REFERENSI}

Aaker, D. A. (1991). Managing Brand Equity: Capitalizing on The Value of.

Anar, A. P. (2018, Februari). Sempat Berseteru, Akhirnya Chef Juna Mengunjungi Toku Kue Coklat di Makassar. Dipetik Juli 2020, dari Rakyatku.com: http://hiburan.rakyatku.com/read/8 7503/2018/02/14/sempatbersetru-akhirnya-chef-junamengunjungi-toku-kue-coklat-dimakassar

Armstrong, K. (2003). Dasar-dasar Pemasaran. Jakarta : PT. Indeks.

Ayu Yuliani. (2019, November). Kemenkop UKM: 3,79 Juta UMKM Sudah Go Online. Dipetik Juli 2020, dari kominfo.go.id: https://kominfo.go.id/content/detail/ 11526/kemenkop-ukm-379-jutaumkm-sudah-goonline/0/sorotan media 
Kartikasari, N. P. (2014). Pengaruh Komunikasi Pemasaran Terpadu terhadap Ekuitas Merek. Interaksi: Jurnal Ilmu Komunikasi,, 3(2), 162167

https://doi.org/10.14710/interaksi.3. 2.162-167.

Keke, Y. (2015). Komunikasi pemasaran terpadu terhadap brand awareness. JURNAL MANAJEMEN BISNIS TRANSPORTASI DAN LOGISTIK, 2(1).

Krussell, J. G., \& Paramita, E. L. (20160. Komunikasi Pemasaran Terpadu Dan Ekuitas Merek Alfamart. BENEFIT: Jurnal Manajemen dan Bisnis, 27-42 https://doi.org/10.23917/benefit.v1i1 .2363.

Kotler, P. \& Keller, K.L. (2009). Manajamen Pemasaran. Jilid I edisi ke 13 Jakarta: Erlangga.
Kotler, P. \& Armstrong, G (2008). Prinsipprinsip Pemasaran,Jilid 1, Erlangga, Jakarta.

Keller, L.L. (1993). Conceptualising, measuring and managing customer based brand equity. Journal of Marketing. (57) 1:1-22.

Pertiwi, W. K. (2020, Februari). Penetrasi Internet di Indonesia Capai 64 Persen. (R. K. Nistanto, Penyunting) Dipetik Juli 2020, dari Kompas.com: https://tekno.kompas.com/read/2020 /02/20/14090017/penetrasiinternet-di-indonesia-capai-64-persen.

Sugiyono. (2012). Metode Penelitian Kuantitatif Kualitatif dan R\&D. Bandung. 